\title{
ENVIRONMENTAL DISASTERS AND PUBLIC SERVICE: THE STATE RESPONSE AND MARKET ACTIVISM
}

\author{
Biswachintamani Ambika Prasad Pani \\ Assistant Registrar (Academics), Nalanda University, Rajgir, Nalanda (Bihar) India \\ Email: ambikaprasadpani@gmail.com
}

\begin{abstract}
While the natural phenomenon or sudden disasters decimate the population on the planet, it is of utmost importance to draw appropriate response to the vagaries of the nature. Though the frequencies of such disasters are not certain, the approach towards protecting the lives and property of the mankind may be pervasive in case of lack of a proper response. While continuous efforts are made by the State in helping the needy at the time of crisis, sometimes the unusual functions of the state indicates it's flaws by enlarging its scope and reach in dealing with disaster management. An attempt has been made here to understand the fundamental role of the State and market in managing disasters starting from resilience to mitigation. This paper also argues that the State directly or indirectly provides a conductive atmosphere for market to function and to become socially responsive and accountable during disasters. Finally this paper throws some light on the approach of the state towards maximum intervention and minimum service which provides ample opportunity to market to establish complex and complicated set of institutional arrangements during disasters.
\end{abstract}

Key words: Market, Response, Disaster Management, Governance, Activism, Public Service

\section{Introduction}

Not only the literature on Ancient India had many references but the history of human civilization indicates a struggle towards escaping from the hazardous disasters of various forms and the havoc caused by those calamitous episodes. At the time of crisis while the role of the state is regarded as primary in order to establish the state's legitimacy, on the other hand in mitigating the worst effects of natural disasters, competitive politics and politics of patronage have occupied the centre stage. While there are various approaches as well as debates on the role of the State, it is also to acknowledge that there are various channels through which a State and other stakeholders interact on policy making, implementation as well as outcome of specific policies. It is indeed a necessity for a State to identify and adopt various approaches to interact and negotiate with various sections of the society at various levels for socio-economic development (Cypher and Dietz, 1997). The same has been observed by scholars like Mark Bevir who argues that State is itself an institution at necessity. Not only in the case of India since neo-liberal reforms but also in the days of economic reform in western countries, the State is overburdened with new, complex and different sets of demands in day-to-day affairs which only requires comparatively competitive and outcome oriented institutions; not by the present State with limited resources and a standard set of bureaucratic procedures (Bevir, 2007). It is of utmost importance to understand a basic difference between the scope, resources and governance procedures of a State and the capacity and capability of a State in meeting the complex demands. At times, when the State is unable to meet the expectations of the stakeholders, some policy analysts term it as a State failure where the market gets an opportunity to extend its services as required by enlarging its scope and limitations. So when the market delivers the services, what the State could not, the market not only overcomes the limitations of the State rather occupies the position as market at possibility. This is certain that 
market at possibility only occurs when there is a State failure and the State directly or indirectly creates a conducive atmosphere for the market to function.

\section{Disaster Management and State Intervention}

From the indispensability necessity nature of the State as opined by Aristotle to monopoly of legitimate constraint as opined by Weber, the State has been recognised as an institution with a set of different roles from time to time. It is very difficult to examine the various roles a State plays at different times and when the role of a State is only limited to managing a disaster, it is quite obvious that the State must put some additional efforts in providing quality of services starting from disaster resilience to mitigation. From disaster recovery efforts to redistribution of resources, sometimes the failure of the state compels the market to play significant role in reducing the looming and immediate threats to life and property of individuals during disasters. It is indeed significant that a pro-active attitude to reduce the toll of disasters in India also requires a more comprehensive approach for the State to adopt which facilitates pre-disaster risk reduction as well as post-disaster recovery. At times of major crisis, the state is viewed as most powerful and visible organization in protection of life and property of the citizens during pre-disaster and deployment of resources for post-disaster relief, reconstruction and recovery. In recent years a paradigm shift has been observed in the role of the state from a reactive postdisaster relief centric to a proactive disaster preparedness and strengthened response capacity. Good governance and responsive administration are outcomes of an effective interface with the citizens/communities at risk from the devastating and hazardous impact of disasters. But it is to note here that irrespective of the changes and improvement in managing the disasters by the state, an attitude of business as usual sometimes hinder the process of managing disasters mostly in case of restoration of disrupted services and protection of life and property of disaster affected communities. Once the role of the state comes prominent and to the forefront, the other measures which are taken by the individuals or other stakeholders/actors voluntarily in managing the effects of the disaster go disregarded.

At the time of disasters, apart from market, the state provides a plenty of opportunities to other players like political parties and political leaders (sometimes apolitical too) to explore for political opportunities and take political mileage. It is sometimes evident in forms of seeking political favours by the affected or victims of disasters to get rehabilitation benefits or restoration reliefs. In this context it is to understand that management of a disaster by the State provides an unsolicited platform directly or indirectly for some sections of the society to gain political mileage or to seek political patronage. The ways through which political patronage like incidents take place certainly causes diverted and diversified attention not only from the core issue i.e. relief from the disasters and disaster management but from various private initiatives taken by market or charity etc. (Mitra, 2000). It is also argued that the neo-liberalism policies as adopted by different States at different times have fundamentally altered the role of the State (Chang, 1994a). The State at present is not in a position to take control of various activities as happen but only probably acts as a facilitator for certain political groups to advance their self-based socio-economic interests (Burlamaqui, Castro and Chang, 2000:3-4).

\section{Decoding Market Activism}

A scholar like Jayal argues that concepts like governance or good governance are completely delinked from democracies or welfarism in a third world context. Because probably the general balance between the governance and a democracy is lost and that's why in third world countries the application of various approaches creates different experiences in consideration of the fact that there is incompatibility among democracy and development. The question arises here whether democracy has been substituted by good governance or governance. The answer to this type of queries clearly denotes the understanding towards creation of minimalist State or 
apparatus institutions (Jayal, 2007). In such cases, development is considered as only a notion which is legally viable rather than any kind of political contestation or approaches. Since there might be an incompatibility between governance and democracy hence considering governance as a technical facilitator and way provider for development to happen does not stand justified which not only delinks governance from development but creates various complexities. When the relationship between development and democracy is looked into, it would be found that there may not be some expected relationship between both. Some undemocratic states also carry a rapid development surge and some democratic states struggle for development. Effective socio-economic development of a nation or a betterment of livelihood of the citizens is not always dependent on democratic or undemocratic nature of a State. In Indian context also, it cannot be assumed that development is always dependent on a better quality of governance and this is evident from the post independent era like the Nehru-Mahalanobis model of development to the SAP reforms of 1991. As discussed earlier, in some contexts, governance has crucial importance over development when notion of freedom is considered as a necessity. Apart from freedom being considered as a right by some constitutional provisions, but a general understanding of the term freedom denotes towards an opportunity created and development is understood as a mere facilitation process to clear various impediments of achieving that freedom. It is quite interesting to place the analysis of Amartya Sen who argued that an effectiveness of a freedom is very much instrumental in promotion and expansion of freedoms of other kinds (Sen, 1999). In consideration of a limited role of the State, it is also argued by scholars and policy analysts that not only spheres of welfarism but also in situation like disasters; the efficiency of market and private players also raises doubt. While economic development is considered as a crucial factor in mitigating the disaster, sometimes it is also argued that facilitating markets in managing many spheres of activity helps in improving economic performance. While sometimes the role of state in managing the disaster becomes marginal due to a number of factors like lack of communication, limited resources etc. the role of market plays an important role in mitigating the impact of disasters to a bare minimum with help of collection of resources, information and cooperation to the needy and required and timely delivery of services with the help of advanced tools and technology etc.

At times, the role of market seems very prominent not only in view of its mere presence but also its efficiency in creation and mobilization of resources and its effective way of information and communication management in providing access to information by the affected citizens or the victims of disaster. It is undoubtedly analysed that the market is outcome oriented and hence it adopts a quite effective way of follow up actions during preparedness, prevention, mitigation, emergency response etc. which at times strengthens the activities and objectives in a more coherent manner. In order to overcome the systemic and procedural inefficiencies, the role of market is very crucial and significant too in the effective management of disasters in India.

\section{Critical Assessment and the Way Ahead}

As per the definition and meaning of Good Governance, an efficient public service, a reliable judiciary and a responsive administration are some of the primary attributes. In the present context, when the market at times is based on notion like effective and efficient management, the key question for the State is which role it should adopt and also in which context. Under certain circumstances, the State needs to take a leadership role. In other situations the general public or the customers do not trust the government and State where the State faces incompetence and complexities and does not have required competence. With an increasing trend being observed in case of natural disasters over the past years, the traditional perception of the idea of calamity relief has been converted into disaster prevention and mitigation of the impact of natural disasters. The extent to which a population is affected by disaster also takes 
into consideration of the prevailing social and economic conditions and its consequential effect on human activities in both pre and post-disaster periods. A solution to the state's unplanned inadequate development activity and the market activism in managing the disasters needs to be planned or executed. It is to note that with the passage of time, the resources, effort and expertise needed in disaster management already exist with the state and its apparatus and nothing new. Mostly streamlining of the integration of various approaches, existing institutional arrangements and deployment of well-equipped/skilled personnel as an initial response to disaster makes the disaster management more effective, efficient and professional. Delineating responsibilities and powers of each entity whether state or market and clear distribution of responsibilities and accountability help in managing a disaster. The process of development must take the aspect of disaster reduction and mitigation within its ambit or else with the state's unusual response and market activism, the development ceases to be sustainable and the disaster eventually causes more hardship and loss to the civilization.

\section{Conclusion}

During the calamities a state possesses a theoretical definite role of a custodian and practically different roles as a facilitator with a number of approaches and channels. As discussed above, the role of state in managing the disaster becomes marginal due to a number of factors like lack of communication, limited resources etc. Whereas, the role of market plays a crucial role in streamlining of the integration of various approaches, existing institutional arrangements and deployment of well-equipped/skilled personnel. The process of development must be kept in mind while taking various approaches towards disaster reduction and mitigation.

\section{References}

1. Bevir, M. (2007). Public Governance. London: Sage Publications.

2. Bhagwati, J. (1993). India in Transition: Freeing the Economy. Oxford: Clarendon Press.

3. Burlamaqui, L., Chang, H.J. \& Castro, A.C. (eds.) (2000). Institutions and the Role of the State. UK: Edward Elgar.

4. Chang, H.J. (1994). The Political Economy of Industrial Policy. UK: Palgrave Macmillan.

5. Cypher, J. M. \& Dietz, J.L. (1997). The Process of Economic Development. London: Routledge.

6. Jayal, N.G. (2007). "The Governance Agenda: Making Democratic Development Dispensable", Economic and Political Weekly, Vol.32, No.8.

7. Jean Dreze and Amartya Sen, (1989). Hunger and Public Action, New Delhi, India: Oxford University Press, pp. 257-79.12.

8. Jean Dreze and Amartya Sen, (1995). India: Economic Development and Social Opportunity New Delhi, India: Oxford University Press, p. 76.

9. John W. Sommer, (1986). "Disaster Unlimited, "The Freeman, April, pp.134-38

10. Kuldeep Mathur and Niraja G. Jayal. (1993). Drought, Policy and Politics: The Need for a Long Term Perspective, New Delhi, India: Sage Publications, pp. 97-125

11. Mathur, K. (2003). Public Policy and Politics in India: How Institutions Matter. New Delhi: Oxford University Press.

12. Migdal, J. S. (2001). State in Society: Studying How States and Societies Transform and Constitute One Another. UK: Cambridge University Press.

13. S. Parasuraman and P. V. Unnikrishnan (eds.) (2000). India's Disaster Reports: Towards a Policy Initiative, New Delhi, India: Oxford University Press, pp.199-200

14. Sen, A. (1999). Development as Freedom. U.K: Oxford University Press.

15. Sharma, S. D. (1998). "Lost between the State and Market", Mershon International Studies Review, Vol.42, No.1, pp.147-150.

16. Susan L. Cutter (ed.) (1993). Environmental Risks and Hazards, Englewood Cliffs, N.J.: Prentice-Hall, pp. 33-54. 